\title{
A Comparative Study of Iranian EFL Teachers' and Learners' Perspectives on Task-based Instruction
}

\author{
Atefeh Hadi \\ English Department, Najafabad Branch, Islamic Azad University, Najafabad, Iran
}

\begin{abstract}
Over the last few decades, Task-Based Instruction (TBI) has gained considerable importance in language teaching research. Yet there are few studies of second language learners' and teachers' perceptions of TBI. This article reports a study that explored teachers' and learners' perceptions of TBI. A sample of 51 Iranian EFL teachers and 88 EFL learners participated in the study. The majority of respondents show positive views on the application of this approach in English classrooms. The results also indicate that Iranian EFL teachers and learners have similar perceptions of TBI.
\end{abstract}

Index Terms - teachers and learners' perceptions, task-based instruction

\section{BACKGROUND}

Insights gained from research in second and foreign language development have made us aware that language learning is primarily a learner-oriented and learning-oriented activity (Brown, 2001; Nunan, 1988; Wright, 1990). Consequently, in recent years there has been more emphasis on the role of the learner in the language learning process. In the same way, learners' perception of language learning is one of the more recently discussed learners' variables in the field. In the context of Task-Based Language Teaching (TBLT), a challenge facing the language teaching profession is to determine how learners perceive and treat the formal and functional properties of language learning tasks (Kumaravadivelus, 1991).

Teachers' perceptions also play an important role in their actual practices while teaching a target language. In their book Psychology for Language Teachers (1997), Williams and Burden argue that teachers are highly influenced by their beliefs. Teachers' beliefs are an extremely complicated phenomenon which involves various aspects, such as beliefs about the nature of language itself, language learning and teaching, learners, teachers, and the teacher-learner power relationship. Such beliefs definitely influence teachers' approaches to EFL teaching. The study of teachers' beliefs forms part of the process of understanding how teachers implement TBI. In order to understand how teachers approach different tasks, it is necessary to understand the beliefs and principles which form the basis of their teaching. Examining language teachers' perceptions should, therefore, help clarify how teachers adapt themselves to communicative language teaching methods including TBLT.

\section{STATEMENT OF PURPose}

Over the years a great deal of research has been carried out into learner and teacher variables which might affect the language learning/teaching process (such as nationality, age, gender, and motivation among many others). But, issues related to teachers' and learners' perceptions of language learning and teaching have not attracted the same degree of attention. Whereas, the language instructors' perceptions of language learning/teaching process has a great influence on what they actually do in practice, and the perceptions of language learners of their own language learning process has an undeniable impact on their learning.

On the other hand, much of the work done in the area of TBLT, has focused on the definitions of task, the role of tasks in second language acquisition (e.g. Ellis 2000; Skehan 1996), different task types (e.g. Skehan \& Foster, 1997), task repetition, and task difficulty. However, there is little practical discussion of how language teachers and learners perceive task based instruction.

Although the foreign language classroom is actually a co-production between teacher and learners, there are a few empirical studies in English as a Second/Foreign Language (ESL/EFL) that look at the teacher and learner together. However, as Kumaravadivelus (1991) asserts, the narrower the gap between the teachers' and the learners' perceptions, the greater the chances of achieving the desired learning outcomes. Hence, the present study argues for the need to embrace the issue of teacher and learner perceptions in the classroom. This attempt aims to help bridge the gap between teacher and learner as a way to enhance the effectiveness of the learning process, because it is believed that the possible differences between teachers and learners' perceptions affect the amount and quality of what learners actually learn. Regarding all the above-mentioned issues, the present study seeks to investigate EFL teachers' perceptions of taskbased language pedagogy. 


\section{A. Research Questions}

This paper aims to address the following research questions in order to shed light upon, and ultimately find a way to improve, EFL classroom teaching practices and pedagogy.

1. How well do Iranian EFL teachers and learners understand TBLT concepts?

2. What are the aspects of Iranian EFL teachers' and learners' views on TBLT implementation?

3. For what practical reasons do Iranian EFL teachers and learners choose, or avoid, implementing TBLT?

4. Is there any significant difference between Iranian EFL learners' and teachers' reported perceptions of task based language instruction?

\section{B. Research Hypothesis}

Based on the fourth research question cited above, this study aims to test the following hypothesis:

H0: There is no significant difference between students' and teachers' reported perceptions of task based language instruction.

\section{METHODOLOGY}

\section{A. Participants}

Group 1: A total of 51 male and female teachers teaching English at "Kish Language Institute" (Isfahan, Iran) participated in the survey. All of the participants had at least two or more years of experience in teaching English as a foreign language. The teachers ranged in age from 20 to 32.

Group 2: A number of 88 female adult learners studying English at "Kish Language Institute" (Isfahan, Iran) language learners formed the second group of the participants in this study. These learners were chosen randomly from different proficiency levels including pre-intermediate, intermediate, upper-intermediate, and advanced learners. They were female with an age range between $16-40$ years.

\section{B. Survey Instruments}

The survey instrument, a questionnaire, was devised to measure Iranian EFL teachers' and learners' perceptions of TBI in classroom setting. This questionnaire was adapted from Jeon's (2005) study. The questionnaire was composed of some Likert-type items and two open-ended questions and was organized into four sections. The first section contained items requesting demographic information from the teachers and learners. The second section dealt with the basic concept of the task and the principles of task-based instruction in order to review the participants' practical understandings of TBI. The third section was related to the participants' views on the classroom practice of TBLT. The questionnaire items were partly adapted and modified from Nunan's (2004) checklist for evaluating communicative tasks. In the second and third sections, teachers and learners were asked to answer each question using a 5-point scale ranging from strongly disagree to strongly agree. Finally, in the fourth section, teachers and learners were asked to check their own reasons for choosing or avoiding the implementation of TBLT, with reference to a few qualitative statements.

The teachers' questionnaire was in English but the learners' was translated into their first language "Farsi". To ensure the validity of the questionnaires and the appropriateness and comprehensibility of the questionnaire items, some experts in the field were consulted. Moreover, the reliability coefficients (Cronbach's alpha) of instruments were estimated in the pilot study. All of the reliability coefficients turned out to be high enough (higher than 0.78 ) to enable the researcher to conduct an statistical analysis of the total of questionnaires.

\section{Data Collection Procedure}

The researcher visited language teachers and learners of the Kish Language Institute, explained the pedagogical goal of the survey, and asked them to fill out the questionnaires. The questionnaires were distributed among teachers. A few of them answered the questionnaire after or in between their class times, but most teachers assigned a time for returning the questionnaire, which was between three to seven days. So the questionnaires were collected one by one over a period of two months. Also, after asking for permission from the teachers of the Kish Language Institute, another set of questionnaires was distributed among the learner participants of the study from 11 different classes in the last 30 minutes of their class time. In this regard, the researcher gave the learners a short explanation about her work as well as directions as to how to fill out the questionnaires. Students were also assured that the information provided by them would be kept confidential. While the learners were filling out the questionnaires, the researcher stayed with them in case there were any ambiguities. As such, it took the researcher about 4 months to collect the learners' questionnaires. The collected data was tabulated to be analyzed. Teachers' and learners' perceptions of TBLT were assessed using the answers which the two groups provided for different parts of the questionnaires. Finally, students' and teachers' reported perceptions were compared to determine the degree of correspondence.

\section{Data Analysis}

The data analysis process consisted of two phases: 
1)The Likert-type items designed to identify teachers' and learners' understandings of TBLT conception and their views on TBLT implementation, were given a numerical score (e.g., strongly disagree $=1$, disagree $=2$, neutral=3, agree $=4$, and strongly agree $=5$ ).

2) In part four of the questionnaire, the participants were asked to choose the reasons for being in favor of TBLT. So, the selected items were given a numerical score of " 1 " and the unselected ones were given " 0 ". Secondly, the participants were asked to choose reasons for having a negative response to TBLT. The selected items were given the numerical score of " 0 " and the unselected ones were given " 1 ".

SPSS (Statistical Package for Social Sciences) version 11.0 for Windows was used to analyze the data. First, measures of frequency (descriptive statistics) were used. In other words, a percentage comparison of teachers' and learners' responses to each of the questionnaire items was carried out in order to indicate how well the learners and teachers understood each of the concepts of TBLT, what kind of views they held when it came to the implementation of TBLT in foreign language classrooms, and the main reasons that learners and teachers chose or avoided implementing TBLT. Consequently, the information gained through the teachers' and learners' questionnaires was analyzed through $t$-tests (inferential statistics) to show the possible significant differences between the two groups' perceptions of TBLT.

\section{RESUlts}

\section{A. Addressing the First Research Question}

Part two of the questionnaire contained seven items dealing with this question:

How well do teachers and learners understand TBLT concepts?

\section{Teacher Results}

TABLE 4.1

INDICATES THE RESULTS OF TEACHERS' RESPONSES TO THIS SECTION.

\begin{tabular}{|l|l|l|l|l|l|}
\hline Question & SA & A & U & D & SD \\
\hline 1 & 22 & 24 & 5 & 0 & 0 \\
\hline 2 & 6 & 30 & 10 & 5 & 0 \\
\hline 3 & 9 & 23 & 8 & 11 & 0 \\
\hline 4 & 14 & 24 & 8 & 5 & 0 \\
\hline 5 & 12 & 34 & 5 & 0 & 0 \\
\hline 6 & 11 & 26 & 8 & 6 & 0 \\
\hline 7 & 15 & 22 & 10 & 4 & 0 \\
\hline
\end{tabular}

As it can be seen in Table 4.1, the majority of the teachers generally agreed with the items, and there was no strong disagreement to any item in any of the sections. For item one "a task is communicative goal directed", for example, while there was no disagreement at all, $43.1 \%$ of the respondents strongly agreed with the idea, $47.1 \%$ agreed, and only 9.8\% were neutral. Regarding item two "a task involves a primary focus on meaning", $11.8 \%$ strongly agreed, $58.8 \%$ agreed, $19.6 \%$ were neutral, and only $9.8 \%$ disagreed, but there was no strong disagreement. The statistics for item three "a task has a clearly defined outcome", included $17.6 \%$ with strong agreement, $45.1 \%$ in agreement, $15.7 \%$ neutral, and $21.8 \%$ in disagreement. Considering item four "a task is any activity in which the target language is used by the learner", $27.4 \%$ of teachers strongly agreed, $47.1 \%$ agreed, $15.7 \%$ were neutral, and only $9.8 \%$ disagreed. For item five "TBLT is consistent with the principles of communicative language teaching", $23.5 \%$ showed strong agreement, $66.7 \%$ showed agreement, and only $9.8 \%$ were neutral, but there was no disagreement. Studying item six "TBLT is based on the student-centered instructional approach" revealed that $21.6 \%$ strongly agreed, $50.9 \%$ agreed, $15.7 \%$ were neutral, and $7.8 \%$ disagreed. Finally, the responses for the last item in this section "TBLT includes three stages: pre-task, task implementation, and post task" comprised of $29.5 \%$ of teachers in strong agreement, $43.1 \%$ in agreement, $19.6 \%$ were neutral, and $7.8 \%$ in disagreement.

\section{Students Results}

TABLE 4.2

SHOWS THE RESULTS OF STUDENTS' REACTIONS TO THIS SECTION.

\begin{tabular}{|l|l|l|l|l|l|}
\hline Question & SA & A & U & D & SD \\
\hline 1 & 30 & 53 & 5 & 0 & 0 \\
\hline 2 & 25 & 51 & 7 & 5 & 0 \\
\hline 3 & 19 & 34 & 30 & 5 & 0 \\
\hline 4 & 23 & 37 & 28 & 0 & 0 \\
\hline 5 & 23 & 55 & 10 & 0 & 0 \\
\hline 6 & 29 & 36 & 18 & 5 & 0 \\
\hline 7 & 27 & 47 & 9 & 5 & 0 \\
\hline \\
Table 4.2.Students' Responses to Section Two (total 88) \\
SA= strongly agree; A= agree; U=neutral; \\
D= disagree; SD= strongly disagree
\end{tabular}


By investigating Table 4.2, it can be found that, as with the teachers, the majority of the students generally agreed with the items, and there was no strong disagreement. For item one "a task is communicative goal directed" $34.1 \%$ of the students strongly agreed and $60.2 \%$ just agreed, but $5.7 \%$ were neutral, and there was no disagreement. Item two "a task involves a primary focus on meaning" had $28.4 \%$ with strong agreement, $58 \%$ in agreement, $7.9 \%$ were neutral responses, and $5.7 \%$ were in disagreement. Regarding item three "a task has a clearly defined outcome", $21.6 \%$ strongly agreed, $38.6 \%$ agreed, $34.1 \%$ were neutral, and $5.7 \%$ disagreed. For item four "a task is any activity in which the target language is used by the learner", saw $26.1 \%$ in strong agreement, $42.1 \%$ in agreement, and $21.8 \%$ were neutral. As with item five "TBLT is consistent with the principles of communicative language teaching", $26.1 \%$ strongly agreed, $62.5 \%$ agreed, and $11.4 \%$ were neutral. Item six "TBLT is based on the student-centered instructional approach" found $33 \%$ of students in strong agreement, $40.9 \%$ in agreement, $20.4 \%$ had neutral responses, and 5.7\% were in disagreement with the statement. Considering the last item, that is, item seven "TBLT includes three stages: pre-task, task implementation, and post-task", $30.7 \%$ strongly agreed, $53.4 \%$ agreed, $10.2 \%$ were neutral, and only $5.7 \%$ of students disagreed.

\section{B. The Second Research Question}

Section three of the questionnaire consisted of eight items which corresponded to the question:

What are the aspects of teachers' and learners' views on TBLT implementation?

\section{Teacher Results}

TABLE 4.3

REVEALS THE RESULTS OF THE TEACHERS' RESPONSES TO THE ITEMS OF THIS SECTION.

\begin{tabular}{|l|l|l|l|l|l|}
\hline Question & SA & A & U & D & SD \\
\hline 1 & 12 & 30 & 5 & 4 & 0 \\
\hline 2 & 14 & 25 & 7 & 5 & 0 \\
\hline 3 & 14 & 25 & 7 & 5 & 0 \\
\hline 4 & 12 & 26 & 7 & 6 & 0 \\
\hline 5 & 10 & 20 & 16 & 5 & 0 \\
\hline 6 & 7 & 23 & 12 & 9 & 0 \\
\hline 7 & 6 & 20 & 20 & 5 & 0 \\
\hline 8 & 27 & 22 & 1 & 1 & 0 \\
\hline
\end{tabular}

By studying Table 4.3, one can find out that there was no strong disagreement with any item and for other items the following results can be found. For item one "I am interested in implementing TBLT in the classroom" $23.6 \%$ strongly agreed, 58.8\% agreed, 9.8\% were neutral, and 7.8\% disagreed. Item two "TBLT provides a relaxed atmosphere to promote the target language use" captured $27.5 \%$ in strong agreement, $49 \%$ in agreement, $13.7 \%$ had neutral responses, and $9.8 \%$ were in disagreement. Considering item three "TBLT activates learners' needs and interests", $27.5 \%$ of teachers were in strong agreement, $47 \%$ in agreement, $13.7 \%$ were neutral, and $9.8 \%$ disagreed with the statement. For item four "TBLT pursues the development of integrated skills in the classroom" $23.6 \%$ strongly agreed, $50.9 \%$ agreed, $13.7 \%$ were neutral, and $11.8 \%$ disagreed. Referring to item five "TBLT gives much psychological burden to teacher as a facilitator", $19.6 \%$ showed strong agreement, 39.2\% showed agreement, $31.4 \%$ were neutral, and 9.8\% showed disagreement. Regarding item six "TBLT requires much preparation time compared to other approaches", there were $13.7 \%$ of teachers in strong agreement, $45.1 \%$ in agreement, $23.6 \%$ were neutral, and $17.6 \%$ were in disagreement. For item seven "TBLT is proper for controlling classroom arrangements", $11.8 \%$ of the respondents strongly agreed, $39.2 \%$ agreed, $39.2 \%$ were neutral, and 9.8\% disagreed. And finally, for item eight "TBLT materials should be meaningful and purposeful based on the real-world context", $52.9 \%$ of the respondents strongly agreed, $43.1 \%$ agreed, $2 \%$ were neutral, and $2 \%$ disagreed.

\section{Student Results}

TABLE 4.4

DEPICTS THE RESULTS OF THE STUDENTS' RESPONSES TO THE ITEMS OF SECTION THREE OF THE QUESTIONNAIRE.

\begin{tabular}{|l|l|l|l|l|l|}
\hline Question & SA & A & U & D & SD \\
\hline 1 & 45 & 38 & 5 & 0 & 0 \\
\hline 2 & 36 & 43 & 9 & 0 & 0 \\
\hline 3 & 30 & 46 & 12 & 0 & 0 \\
\hline 4 & 30 & 41 & 12 & 5 & 0 \\
\hline 5 & 34 & 44 & 10 & 0 & 0 \\
\hline 6 & 19 & 35 & 28 & 6 & 0 \\
\hline 7 & 15 & 48 & 20 & 5 & 0 \\
\hline 8 & 26 & 38 & 19 & 5 & 0 \\
\hline
\end{tabular}


Once again, Table 4.4 shows that there was no strong disagreement for any of the items in this section. Other results which were drawn are as follows. Regarding strong agreement, item one "I am interested in implementing TBLT in the classroom" captured $51.1 \%$ of the responses, item two "TBLT provides a relaxed atmosphere to promote the target language use" 40.9\%, item three "TBLT activates learners' needs and interests" $34.1 \%$, item four "TBLT pursues the development of integrated skills in the classroom" $34.1 \%$, item five "TBLT gives much psychological burden to teacher as a facilitator" $38.6 \%$, item six "TBLT requires much preparation time compared to other approaches" $21.6 \%$, item seven "TBLT is proper for controlling classroom arrangements" $17.1 \%$, and item eight "TBLT materials should be meaningful and purposeful based on the real-world context" 29.5\%. Considering agreement, $43.2 \%$ of the respondents chose this option for item one, $48.9 \%$ for item two, $52.3 \%$ for item three, $46.6 \%$ for item four, $50 \%$ for item five, $39.8 \%$ for item six, $54.5 \%$ for item seven, and $43.2 \%$ for item eight. For neutral option, item one attracted $5.7 \%$, item two $9 \%$, item three $13.6 \%$, item four $5.7 \%$, item five $11.4 \%$, item six $6.8 \%$, item seven $5.7 \%$, and item eight $5.7 \%$. And finally, for disagree option, there was no disagreement for items one, two, three, and five, but for item four there was $5.7 \%$ disagreement, for item six $6.8 \%$, for item seven $5.7 \%$ and for item eight $5.7 \%$.

\section{The Third Research Question}

Section four of the questionnaire contained one yes/no question which was related to this research question:

For what practical reasons do teachers and learners choose, or avoid, implementing TBLT?

If the respondents answered 'Yes', they had to tick any or all of the five reasons that followed, but if they answered 'No', they had six reasons to choose from. Table 4.5 shows the number of reasons teachers and students presented for using TBLT.

TABLE 4.5

THE NUMBER OF REASONS PRESENTED BY TEACHERS AND STUDENTS FOR IMPLEMENTING TBLT

\begin{tabular}{|l|l|l|}
\hline Reason No. & Teachers & Students \\
\hline 1 & 16 & 32 \\
\hline 2 & 39 & 71 \\
\hline 3 & 30 & 50 \\
\hline 4 & 40 & 66 \\
\hline 5 & 17 & 63 \\
\hline
\end{tabular}

According to Table 4.5, reason one "TBLT promotes learners' academic progress" attracted 31.4\% of teachers' votes and $36.4 \%$ of students' votes, reason two "TBLT improves learners' interaction skills" found $76.5 \%$ of teachers and $80.7 \%$ of students voting, reason three "TBLT encourages learners' intrinsic motivation" was voted for by $58.8 \%$ of teachers and $56.8 \%$ of students, reason four "TBLT creates a collaborative learning environment" was chosen by $78.4 \%$ of teachers and $75 \%$ of students, and finally, reason five "TBLT is appropriate for small group work" attracted $33.3 \%$ of teacher votes and $71.6 \%$ of student votes. The numbers of participants who chose the 'No' option is presented in Table 4.6 .

TABLE 4.6.

THE NUMBER OF REASONS PRESENTED BY TEACHERS AND STUDENTS FOR NOT IMPLEMENTING TBLT

\begin{tabular}{|l|l|l|}
\hline Reason No. & Teachers & Students \\
\hline 1 & 13 & 28 \\
\hline 2 & 6 & 23 \\
\hline 3 & 9 & 7 \\
\hline 4 & 13 & 21 \\
\hline 5 & 13 & 32 \\
\hline 6 & 13 & 28 \\
\hline
\end{tabular}

It can be seen in Table 4.6 that $25.5 \%$ of the teachers and $31.8 \%$ of the students chose the first reason " not being used to task-based instruction", $11.8 \%$ of the teachers and $26.1 \%$ of the students chose reason two "materials in the textbooks are not proper for using TBLT", $17.7 \%$ of the teachers and $8 \%$ of the students chose reason three "large class size is an obstacle to use task-based methods", $25.5 \%$ of the teachers and $23.9 \%$ of the students chose reason four which deals with "difficulty in assessing learners' task-based performance", $25.5 \%$ of the teachers and $36.4 \%$ of the students chose reason five that is "teachers' limited target language proficiency", and $25.5 \%$ of the teachers and $31.8 \%$ of the students selected reason six which refers to "teachers' little knowledge of task-based instruction".

\section{Investigating the Null hypothesis}

The null hypothesis investigates:

If there is any significant difference between students' and teachers' reported perceptions of TBLT.

To test the validity of this hypothesis the results of the teachers' and students' responses to different sections of the questionnaire were compared separately. Table 4.7 presents the descriptive statistics for teachers and students responses for each item in section two, and Figure 4.1 illustrates the means graphically. 
TABLE 4.7.

DESCRIPTIVE STATISTICS FOR TEACHERS AND STUDENTS RESPONSES TO SECTION TWO

\begin{tabular}{|c|c|c|c|c|c|}
\hline Item & Group & No & Mean & $\mathrm{SD}$ & SEM \\
\hline \multirow{2}{*}{$\begin{array}{l}\text { 1. A task is a communicative goal } \\
\text { directed. }\end{array}$} & Teachers & 51 & 4.39 & .603 & .084 \\
\hline & Students & 88 & 4.28 & .566 & .060 \\
\hline $\begin{array}{l}\text { 2. A task involves a primary focus on } \\
\text { meaning. }\end{array}$ & Teachers & 51 & 3.73 & .802 & .112 \\
\hline \multirow[t]{2}{*}{ 3. A task has a clearly defined outcome. } & Teachers & 51 & 3.59 & 1.023 & .143 \\
\hline & Students & 88 & 3.76 & .858 & .091 \\
\hline $\begin{array}{l}\text { 4. A task is any activity in which the } \\
\text { target language is used by the learner. }\end{array}$ & Teachers & 51 & 3.92 & .913 & .128 \\
\hline \multirow{2}{*}{$\begin{array}{l}\text { 5. TBLT is consistent with the principles } \\
\text { of communicative language teaching. }\end{array}$} & Teachers & 51 & 4.20 & .530 & .074 \\
\hline & Students & 88 & 4.15 & .598 & .064 \\
\hline \multirow{2}{*}{$\begin{array}{l}\text { 6. TBLT is based on the student-centered } \\
\text { instructional approach. }\end{array}$} & Teachers & 51 & 3.82 & .910 & .127 \\
\hline & Students & 88 & 4.01 & .878 & .094 \\
\hline $\begin{array}{l}\text { 7. TBLT includes three stages: pre-task, } \\
\text { task implementation, and post-task. }\end{array}$ & Teachers & 51 & 3.94 & .904 & .127 \\
\hline
\end{tabular}

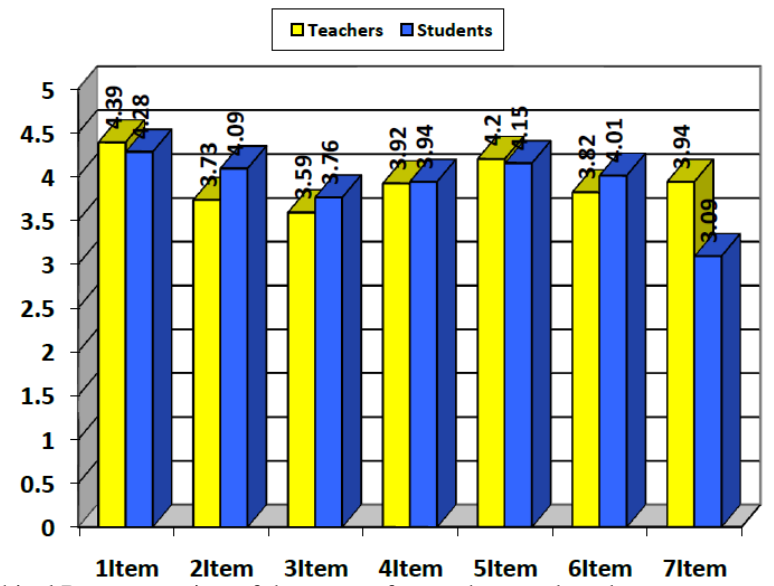

Figure 4.1.Graphical Representation of the means for teachers and students responses to Section Two.

As can be seen in the 'mean' column of Table 4.7, the means for teachers and students are different. In order to find out whether these differences are statistically significant or not, a number of $t$-tests were employed. Table 4.8 reveals the results of these $t$-tests.

TABLE 4.8.

THE RESULTS OF THE T-TESTS FOR THE COMPARISON OF TEACHERS' AND STUDENTS' RESPONSES TO SECTION TWO

\begin{tabular}{lllll}
\hline Item & T & df & Sig. & Mean Difference \\
\hline 1 & 1.059 & 137 & .291 & .108 \\
\hline 2 & -2.441 & 137 & .009 & -.365 \\
\hline 3 & -1.068 & 137 & .288 & -.173 \\
\hline 4 & -.150 & 137 & .881 & -.022 \\
\hline 6 & .479 & 137 & .633 & .048 \\
\hline 7 & -1.200 & 137 & .232 & -.188 \\
\hline
\end{tabular}

By investigating Table 4.8, one can find out that the amount of t-observed is significant only for item number $2 ; \mathrm{t}$ $(137)=-2.441, p=.009$, but for other items the difference between teachers' responses and students' responses are not statistically significant.

The next series of comparisons were made between the teachers' and students' responses to section three of the questionnaire. Table 4.9 reveals the descriptive statistics for this comparison, and Figure 4.2 shows the means graphically. 
TABLE 4.9.

DESCRIPTIVE STATISTICS FOR TEACHERS' AND STUDENTS' RESPONSES TO SECTION THREE

\begin{tabular}{|c|c|c|c|c|c|}
\hline Item & Group & No & Mean & SD & SEM \\
\hline 1. I am interested in implementing & Teachers & 51 & 3.98 & .812 & .114 \\
\hline TBLT in the classroom. & Students & 88 & 4.47 & .586 & .063 \\
\hline 2. TBLT provides a relaxed & Teachers & 51 & 3.96 & .871 & .122 \\
\hline \multirow{2}{*}{$\begin{array}{l}\text { 3. TBLT activates learners' needs and } \\
\text { interests. }\end{array}$} & Teachers & 51 & 3.96 & .871 & .122 \\
\hline & Students & 88 & 4.21 & .664 & .071 \\
\hline $\begin{array}{l}\text { 4. TBLT pursues the development of } \\
\text { integrated skills in the classroom. }\end{array}$ & Students & 88 & 4.09 & .839 & .089 \\
\hline \multirow{2}{*}{$\begin{array}{l}\text { 5. TBLT gives much psychological } \\
\text { burden to teacher as a facilitator. }\end{array}$} & Teachers & 51 & 3.69 & .905 & .127 \\
\hline & Students & 88 & 4.27 & .656 & .070 \\
\hline \multirow{2}{*}{$\begin{array}{l}\text { 6. TBLT requires much preparation } \\
\text { time compared to other approaches. }\end{array}$} & Teachers & 51 & 3.55 & .945 & .132 \\
\hline & Students & 88 & 3.76 & .871 & .093 \\
\hline \multirow{2}{*}{$\begin{array}{l}\text { 8. TBLT materials should be } \\
\text { meaningful and purposeful based on } \\
\text { the real-world context. }\end{array}$} & Teachers & 51 & 4.47 & .644 & .090 \\
\hline & Students & 88 & 3.97 & .864 & .092 \\
\hline
\end{tabular}

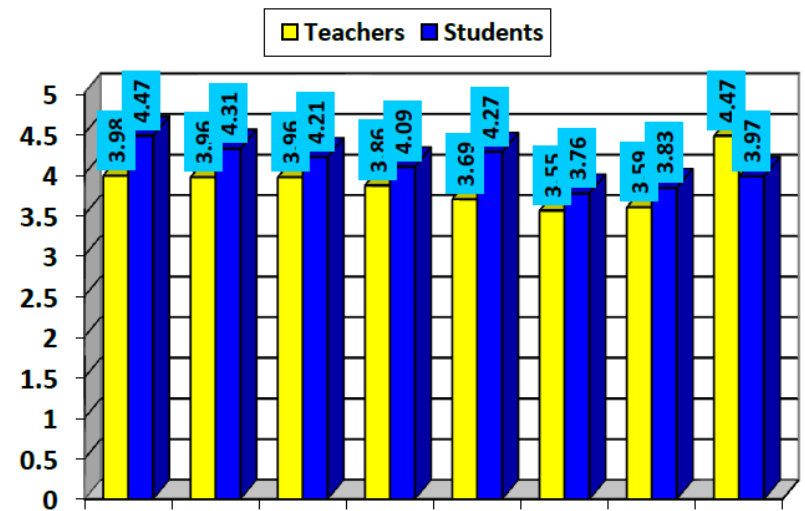

1Item 2Item 3Item 4Item 5Item 6Item 7ltem 8Item

Figure 4.2. Graphical Representation of Means for Teachers' and Students' Responses to Section Three

Studying the means in Figure 4.2 shows that there are differences between each pair of means. In order to see if the differences are statistically significant or not, another series of t-tests was employed. Table 4.10 presents the results of these $t$-tests.

TABLE 4.10

RESULTS OF T-TESTS FOR THE COMPARISON OF TEACHERS’ AND STUDENTS' RESPONSES TO SECTION THREE

\begin{tabular}{lllll}
\hline Item & $\mathrm{t}$ & $\mathrm{df}$ & Sig. & Mean Difference \\
\hline 1 & -4.072 & 137 & .000 & -.486 \\
\hline 2 & -2.664 & 137 & .009 & -.346 \\
\hline 3 & -1.857 & 137 & .065 & -.244 \\
\hline 4 & -1.493 & 137 & .138 & -.228 \\
\hline 6 & -4.404 & 137 & .000 & -.587 \\
\hline 7 & -1.343 & 137 & .182 & -.212 \\
\hline 8 & -1.723 & 137 & .087 & -.241 \\
\hline
\end{tabular}

As Table 4.10 shows that $t$ is significant for items one; $\mathrm{t}(137)=-4.072, \mathrm{p}=.000$, two; $\mathrm{t}(137)=-2.644, \mathrm{p}=.009$, five; $\mathrm{t}$ $(137)=-4.404, p=.000$; and eight $\mathrm{t}(137)=3.628, \mathrm{p}=.000$; but is not significant for items three, four, six, and seven. So the hypothesis is rejected with respect to items one, two, five, and eight, but it is retained for items three, four, six and seven.

A third series of comparisons were made between teachers' and students' reason for using TBLT. Table 4.11 indicates the descriptive statistics for this set of data, and figure 4.3 graphically illustrates the mean values. 
TABLE 4.11

DESCRIPTIVE STATISTICS FOR TEACHERS’ AND STUDENTS’ RESPONSES TO USING TBLT

\begin{tabular}{|c|c|c|c|c|c|}
\hline Item & Group & No & Mean & SD & SEM \\
\hline 1. TBLT promotes learners' academic & Teachers & 51 & .314 & .469 & .066 \\
\hline progress. & Students & 88 & .364 & .484 & .052 \\
\hline 2. TBLT improves learners' & Teachers & 51 & .765 & .428 & .060 \\
\hline interaction skills. & Students & 88 & .807 & .397 & .042 \\
\hline 3. TBLT encourages learners' intrinsic & Teachers & 51 & .588 & .497 & .070 \\
\hline motivation. & Students & 88 & .568 & .498 & .053 \\
\hline 4. TBLT creates a collaborative & Teachers & 51 & .784 & .415 & .058 \\
\hline learning environment. & Students & 88 & .750 & .436 & .046 \\
\hline 5. TBLT is appropriate for small & Teachers & 51 & .333 & .476 & .067 \\
\hline group work. & Students & 88 & .716 & .454 & .048 \\
\hline
\end{tabular}

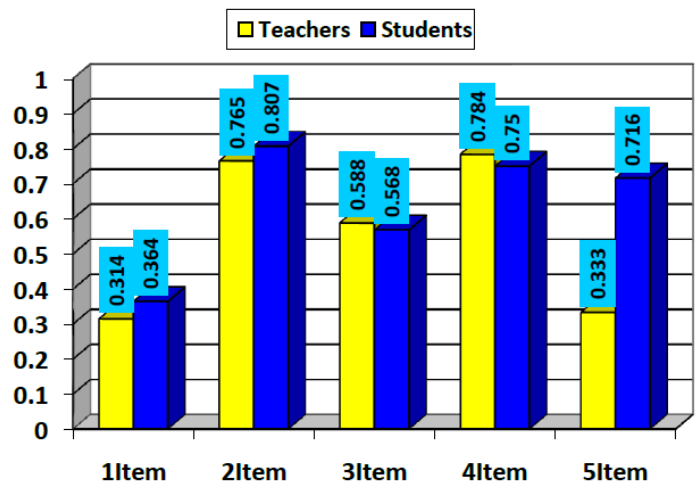

Figure 4.3. Graphical Representation of the Mean values for Teachers' and Students' Responses to Using TBLT

By studying the means in Figure 4.2, one understands that there are differences between the means in each pair. A third set of t-tests was implemented to check the significance of these differences. Table 4.12 shows the results of the $t-$ tests.

TABLE 4.12.

THE RESULTS OF THE T-TESTS FOR THE COMPARISON OF TEACHERS’ AND STUDENTS' RESPONSES FOR USING TBLT

\begin{tabular}{lllll}
\hline Item & $\mathrm{t}$ & $\mathrm{df}$ & Sig. & Mean Difference \\
\hline 1 & -.593 & 137 & .554 & -.050 \\
\hline 2 & -.585 & 137 & .559 & -.042 \\
\hline 3 & .229 & 137 & .819 & .020 \\
\hline 4 & .455 & 137 & .650 & .034 \\
\hline 5 & -4.706. & 137 & .000 & -.383 \\
\hline
\end{tabular}

An investigation of the information in Table 4.12, will find that the amount of t-observed is significant only for item five; $\mathrm{t}(137)=-4.706, \mathrm{p}=.000$, but it is not significant for items one, two, three, and four. Therefore, the hypothesis is only rejected with respect to item five, but it is retained for all other items. Thus, it can be claimed that the teachers and the students have almost the same reasons for choosing TBLT.

The last comparison looked at the reasons given by the teachers and the students for not using TBLT. Table 4.13 reveals the descriptive statistics for this last set of comparisons, and Figure 4.4 depicts the means in bar form.

TABLE 4.13.

DESCRIPTIVE STATISTICS FOR TEACHERS' AND STUDENTS' RESPONSES TO NOT USING TBLT

\begin{tabular}{|c|c|c|c|c|c|}
\hline Item & Group & No & Mean & SD & SEM \\
\hline \multirow{2}{*}{$\begin{array}{l}\text { 1. Students are not used to task-based } \\
\text { learning. }\end{array}$} & Teachers & 51 & .255 & .440 & .062 \\
\hline & Students & 88 & .318 & .468 & .050 \\
\hline $\begin{array}{l}\text { 2. Materials in textbooks are not } \\
\text { proper for using TBLT. }\end{array}$ & Teachers & 51 & .118 & .325 & .046 \\
\hline \multirow{2}{*}{$\begin{array}{l}\text { 3. Large class size is an obstacle to } \\
\text { use task-based methods. }\end{array}$} & Teachers & 51 & .177 & .385 & .054 \\
\hline & Students & 88 & .080 & .272 & .029 \\
\hline $\begin{array}{l}\text { 4. I have difficulty in assessing } \\
\text { learner's task-based performance. }\end{array}$ & Teachers & 51 & .255 & .440 & .062 \\
\hline \multirow{2}{*}{$\begin{array}{l}\text { 5. I have limited target language } \\
\text { proficiency. }\end{array}$} & Teachers & 51 & .255 & .440 & .062 \\
\hline & Students & 88 & .364 & .484 & .052 \\
\hline \multirow{2}{*}{$\begin{array}{l}\text { 6. I have very little knowledge of task- } \\
\text { based instruction. }\end{array}$} & Teachers & 51 & .255 & .440 & .062 \\
\hline & Students & 88 & .318 & .468 & .050 \\
\hline
\end{tabular}




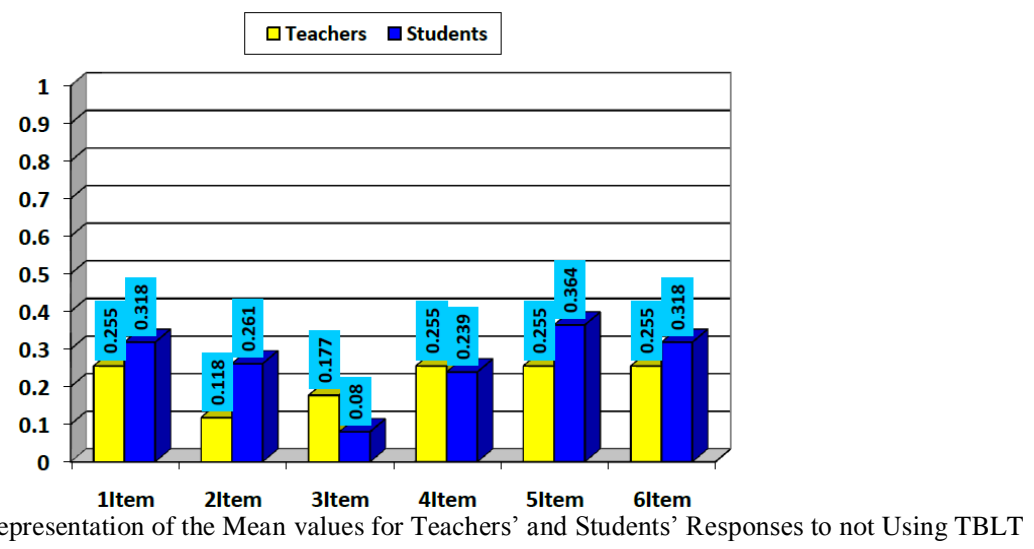

Figure 4.2 indicates that there are differences between the means in each pair. A final set of t-tests was employed to check the significance of these differences. Table 4.14 shows the results of these $t$-tests.

TABLE 4.14

THE RESULTS OF T-TESTS FOR THE COMPARISON OF TEACHERS' AND STUDENTS' RESPONSES TO NOT USING TBLT

\begin{tabular}{lllll}
\hline Item & $\mathrm{t}$ & $\mathrm{df}$ & Sig. & Mean Difference \\
\hline 1 & -.785 & 137 & .434 & -.063 \\
\hline 2 & -2.025 & 137 & .045 & -.144 \\
\hline 3 & 1.732 & 137 & .086 & .097 \\
\hline 4 & .213 & 137 & .083 & .016 \\
\hline 5 & -1.319 & 137 & .189 & -.109 \\
\hline
\end{tabular}

Through investigating the information in Table 4.12, it can be seen that the value of t-observed is significant only for item two; $\mathrm{t}(137)=-2.025, \mathrm{p}=.045$, but is not significant for items one, three, four, five, and six. The result of all these t-tests, sees the hypothesis rejected only with respect to item two, but it is retained for all other items. Therefore, it can be claimed that teachers and students have almost the same reasons for deciding not to use TBLT.

\section{DisCUSSION AND CONCLUSION}

The analysis of results concerning the first research question showed that teachers and learners both had a firm grasp of the linguistic characteristics of TBLT which approves the teaching advantages of TBLT in learning a second language. These findings are not surprising and are in tune with the previous findings that have shown that teachers convey a considerable amount of practical understanding about the key concepts of TBLT (Jeon, 2005; Zare, 2007).

According to Jeon (2005), this could be the consequence of the shift that the Asian EFL context has made toward the use of a task-based and activity-oriented type of learning a language to improve the learners' communicative skills. This finding also supports the findings of the study conducted by Zare (2007), who examined the attitudes of Iranian EFL learners and teachers towards TBLT after they were exposed to and applied TBLT, respectively. The results showed that the Iranian EFL learners and teachers had a positive attitude towards TBLT.

Concerning the second research question, the analysis of results indicated that the participants actually held positive views on implementing TBLT in English language classrooms. They seemed to be willing to adapt themselves to the new language learning/teaching approach. These results contradict the findings of previous studies that have shown, despite the comparatively higher-level understanding of TBLT concepts, many teachers actually hesitated to adopt TBLT as an instructional method in classroom practice (Jeon, 2005). Jeon argues that teachers' conceptual understandings of TBLT do not necessarily lead to the actual use of TBLT in the classroom. This may result from the fact that most Korean EFL teachers still use the traditional lecture-oriented methods, which they are accustomed to, and furthermore, they have the psychological pressure of facing new disciplinary problems when using TBLT (Jeon, 2005).

The findings which relate to the second research question are consistent with the findings of Zare's (2007) study, in which it is argued that Iranian EFL learners and teachers who participated in the study welcomed the new experience. Zare asserts that the educational environment to which the people are accustomed can have some effect on their attitudes towards methods of language teaching and these attitudes can sometimes prevent or delay the acceptance of new methods of language teaching. On the other hand, he argues that these attitudes are not innate and can be changed through exposure to a new method of teaching.

In response to the third research question in which the practical reasons why teachers and learners chose or avoided implementing TBLT, the answers to the two open-ended items were analyzed. The findings revealed that teachers' and learners' reasons for willingness or reluctance toward TBLT application vary. The majority of teachers and learners were in favor of task-based methods firstly because of its collaborative and interactional nature and then its motivational 
potential. While a large number of learners favored TBLT due to its appropriateness for small group-work, and for them this reason came before motivation. These findings are in agreement with the findings of other researchers such as Jeon (2005). According to him, Korean EFL teachers appreciate the fact that TBLT increases learners' motivation and smallgroup interaction.

The majority of teachers who were against task-based implementation, were afraid of being faced with problems due to not being knowledgeable enough about TBLT, limited target language proficiency, and not being accustomed to TBLT. There are still many problems that teachers come across when using TBLT which they can lessen by trying to understand its' advantages and to fashion a positive view toward it as an instructional method. Firstly, it's necessary for teachers to learn the weaknesses and strengths of a task-based methodology, and to understand its basic principles other than its diversity of techniques.

For the learners who were rarely trained in task-based learning, the most important reason why they avoided participating in task-based activities was that they did not find their teachers proficient enough in the target language. They believed that their teachers did not have the necessary experience and mastery to implement TBLT. Moreover, most of the learners were not used to TBLT. They were accustomed to the traditional lecture-oriented methods and teacher-centered classrooms. It is not surprising, because communicative language learning and especially task-based language learning are not practiced in the educational system of Iran. When it comes to task performance, learners do not have the required confidence. Therefore, it is teachers' responsibility to encourage learners, inspire their confidence and help them learn collaborative skills necessary for successful completion of task-based activities; because learners' active participation in task-based performance is the essence of successful language learning process. When learners understand that task-based activities are simply one of the many ways of language learning, they will effectively manage to deal will the tasks. Thus, confidence-building exercises may result in improving learners' active participation and a shift toward more learner-centered classroom (Burdett, 2003).

These findings are in line with those of Zare (2007), who proposed that teachers can hope to successfully apply TBLT in their classes while learners adapt themselves to this new approach of language teaching. This can be true not only at the level of private institutes, but also at the level of public schools. In other words, one can hope to institutionalize the culture of TBLT in public schools as well, though this process may cause the teacher to have to overcome some initial cultural and managerial problems. Moreover, it is clear that such a change can take place only gradually.

Although teachers are reluctant to use the TBLT due to the difficulty in evaluating learner's task-based performance, performance evaluation must be given notice. In terms of group evaluation, giving the same score to every member may be a downside of trying to have a reasonable evaluation, especially in high achieving learner groups. As a result, to intensify the participation and quality of involvement in task-based group work, the teacher must consider both intergroup and intra-group evaluations (Lourdusamy \& Divaharan, 2002). Contrary to the inter-group assessment which uses the groups' products as part of the course evaluation which results in giving equal grades to all members, the intragroup assessment deals with individual evaluation.

The other obstacles mentioned by L2 learners were the inappropriateness of text book materials and not having a clear understanding of their progress in the language while being taught in TBLT. Concerning task-based materials, few teachers indicated that the materials in the textbooks were the reason they didn't use task-based techniques in their classrooms. This somehow shows that the present EFL textbooks available in Iran, many of which follow the principles of the communicative theory of language learning, correctly reflect the task-based syllabus which mainly concerns communicative skills and social interaction. In addition, it shows that at times it's necessary for teachers to redesign textbook materials to make them suitable for interaction and collaborative learning.

Concerning big classes which are mostly problematic to control in task-based group work, the teacher must consider each groups formation and presentation. Besides the fact that big classes are time consuming to prepare, task-based techniques can be similarly used in both small and big classes.

Considering the forth research question, the comparison of teachers' and learners' data showed that EFL teachers and learners have almost the same understanding of TBLT concepts. Only in one case the difference in teachers' and learners" perceptions of TBLT concepts and principles seemed to be different; that is, item 2 "A task involves a primary focus on meaning". The number of learners who agreed with the idea of the meaning focused nature of tasks was significantly more than teachers.

The next series of comparisons showed that there were significant differences between teachers' and learners' views on TBLT implementation regarding item 8 "I am interested in implementing TBLT in the classroom", item 9 "TBLT provides a relaxed atmosphere to promote the target language use", item 12 "TBLT gives much psychological burden to teacher as a facilitator", and item 15 "TBLT materials should be meaningful and purposeful based on the real-world context. It can be inferred that learners have more positive views than teachers on TBLT implementation. As the number of learners showing interest in TBLT implementation, believing in the relaxed atmosphere created by TBLT, and accepting the facilitator role of the teacher was significantly higher than teachers. Respectively, the result revealed that compared with learners, teachers agreed that implementing TBLT required more authentic and purposeful materials

According to the results of this study, it can be claimed that all participants, teachers and learners had nearly the same reasons for choosing TBLT, and there was only a significant difference between the two groups for item 5 "TBLT is 
appropriate for small group-work". Learners believed that TBLT was more appropriate for small group work than teachers. The only significant difference between learners' and teachers' reasons for avoiding TBLT was found in item 2, that is, "materials in textbooks are not proper for using TBLT. Therefore, it can be claimed that compared with teachers, most students did not find text book materials suitable for task-based instruction.

The findings of the study addressing the last research question showed that the existing differences between Iranian EFL teachers' and learners' perceptions of TBLT are not significant. These findings are clearly in contrast with the results of previous studies that have shown evident differences between the teacher and learners' perceptions of TBLT (Kumaravadivelu, 1991; Slimani, 1989; Block, 1994, 1996; Barkhuizhen 1989).

\section{IMPLICATIONS}

Concerning the results of the study, some notifying suggestions are given to teachers and teacher trainers. First, because teachers' and learners' attitudes toward instructional approaches highly influence classroom practice, it is necessary for the teachers and learners to have a positive attitude toward TBLT so that it can be successfully used. Second, because some teachers know little about applying task-based methods or techniques, they should be given the chance to educate themselves in fields relating to the planning, the putting into practice, and evaluation of TBLT.

It is believed that the results of this study will have implications for syllabus and material designers and classroom practice. Once curriculum developers and syllabus designers come to know how teachers and students perceive taskbased language instruction, they can take into consideration those perceptions and plan alternative materials and activities in their syllabi to make the language learning-teaching process a more effective and enjoyable one. Similarly, foreign language teachers' awareness of the way their students perceive TBLT will help them reconsider how to manage and organize classroom behavior and improve their practice. Even if learners' desires and those of teachers' are in contrast with each other, they can shift to a negotiated syllabus procedure and come to reasonable agreement (Jordan, 1997). Finally, given the novelty of TBLT in the context of Iran, this study will hopefully pave the way for further research on TBI.

\section{APPENDICES}

\section{A. Teacher Questionnaire}

This questionnaire is designed to examine Iranian EFL teachers' perceptions of Task-Based Language Teaching (TBLT) with reference to classroom practice. I would be really grateful if you read each item carefully and provide an answer. Your answers will be kept confidential. Thank you for your cooperation.

Section I. General and Demographic Information

\begin{tabular}{|c|c|c|c|c|}
\hline Gender & amale & $\square$ female & & \\
\hline Age & $\square 20-25$ & $\square 25-30$ & $\square 30-35$ & $\square 35+$ \\
\hline $\begin{array}{l}\text { Total number of years } \\
\text { teaching English }\end{array}$ & aless than 2 years & $\square 2$ to 6 years & $\square 6$ to10 years & $\square$ more than 10years \\
\hline
\end{tabular}

\section{Section II. Teachers' Understandings of Task and TBLT}

For each of the following statements, please answer by putting a $\sqrt{ }$ in a box, according to the following scale:

SA (strongly agree), A (agree), U (undecided), D (disagree), SD (strongly disagree).

\begin{tabular}{|c|c|c|c|c|c|}
\hline Questionnaire Items & SA & A & $\mathrm{U}$ & $\mathrm{D}$ & SD \\
\hline 1. A task is communicative goal directed. & $\square$ & $\square$ & $\square$ & $\square$ & $\square$ \\
\hline 2. A task involves a primary focus on meaning. & $\square$ & $\square$ & $\square$ & $\square$ & $\square$ \\
\hline 3. A task has a clearly defined outcome. & $\square$ & $\square$ & $\square$ & $\square$ & $\square$ \\
\hline 4. A task is any activity in which the target language is used by the learner. & $\square$ & $\square$ & $\square$ & $\square$ & $\square$ \\
\hline 5. TBLT is consistent with the principles of communicative language teaching. & $\square$ & $\square$ & $\square$ & $\square$ & $\square$ \\
\hline 6. TBLT is based on the student-centered instructional approach. & $\square$ & $\square$ & $\square$ & $\square$ & $\square$ \\
\hline 7. TBLT includes three stages: pre-task, task implementation, and post-task. & $\square$ & $\square$ & $\square$ & $\square$ & $\square$ \\
\hline
\end{tabular}

\section{Section III. Teachers' Views on Implementing TBLT}

The following statements address teachers' views on implementing TBLT in the classroom. Please answer by putting a $\sqrt{ }$ in a box that matches your position most, according to the following scale:

SA (strongly agree), A (agree), U (Undecided), D (disagree), SD (strongly disagree).

\begin{tabular}{|c|c|c|c|c|c|}
\hline Questionnaire Items & SA & A & $\mathrm{U}$ & $\mathrm{D}$ & $\mathrm{SD}$ \\
\hline 8. I am interested in implementing TBLT in the classroom. & $\square$ & $\square$ & $\square$ & $\square$ & $\square$ \\
\hline 9. TBLT provides a relaxed atmosphere to promote the target language use. & $\square$ & $\square$ & $\square$ & $\square$ & $\square$ \\
\hline 10. TBLT activates learners' needs and interests. & $\square$ & $\square$ & $\square$ & $\square$ & $\square$ \\
\hline 11. TBLT pursues the development of integrated skills in the classroom. & $\square$ & $\square$ & $\square$ & $\square$ & $\square$ \\
\hline 12. TBLT gives much psychological burden to teacher as a facilitator. & $\square$ & $\square$ & $\square$ & $\square$ & $\square$ \\
\hline 13. TBLT requires much preparation time compared to other approaches. & $\square$ & $\square$ & $\square$ & $\square$ & $\square$ \\
\hline 14. TBLT is proper for controlling classroom arrangements. & $\square$ & $\square$ & $\square$ & $\square$ & $\square$ \\
\hline 15. TBLT materials should be meaningful and purposeful based on the real-world context. & $\square$ & $\square$ & $\square$ & $\square$ & $\square$ \\
\hline
\end{tabular}


Section IV. Reasons Teachers Choose or Avoid Implementing TBLT

Do you use TBLT in your teaching? $\square$ YES $\square$ NO

If yes, please put a $\sqrt{ }$ for any reasons that make you decide to implement TBLT.

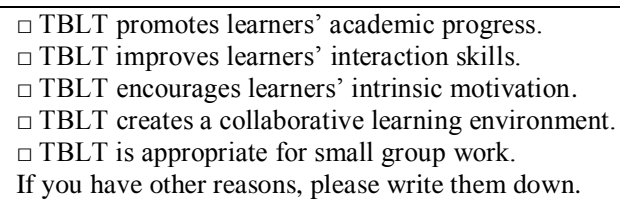

If no, please put a $\sqrt{ }$ for any reasons that make you avoid implementing TBLT.

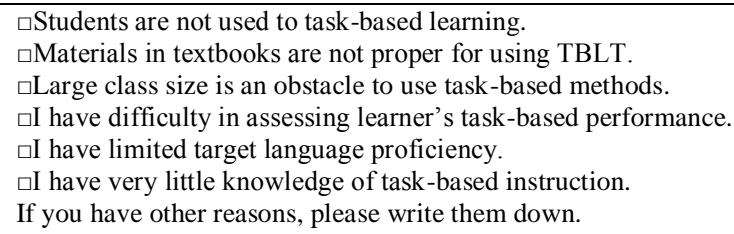

\section{B. Learner Questionnaire}

This questionnaire is designed to examine Iranian EFL learners' perceptions of Task-Based Language Teaching (TBLT) with reference to classroom practice. I would be really grateful if you read each item carefully and provide an answer. Your answers will be kept confidential. Thank you for your cooperation.

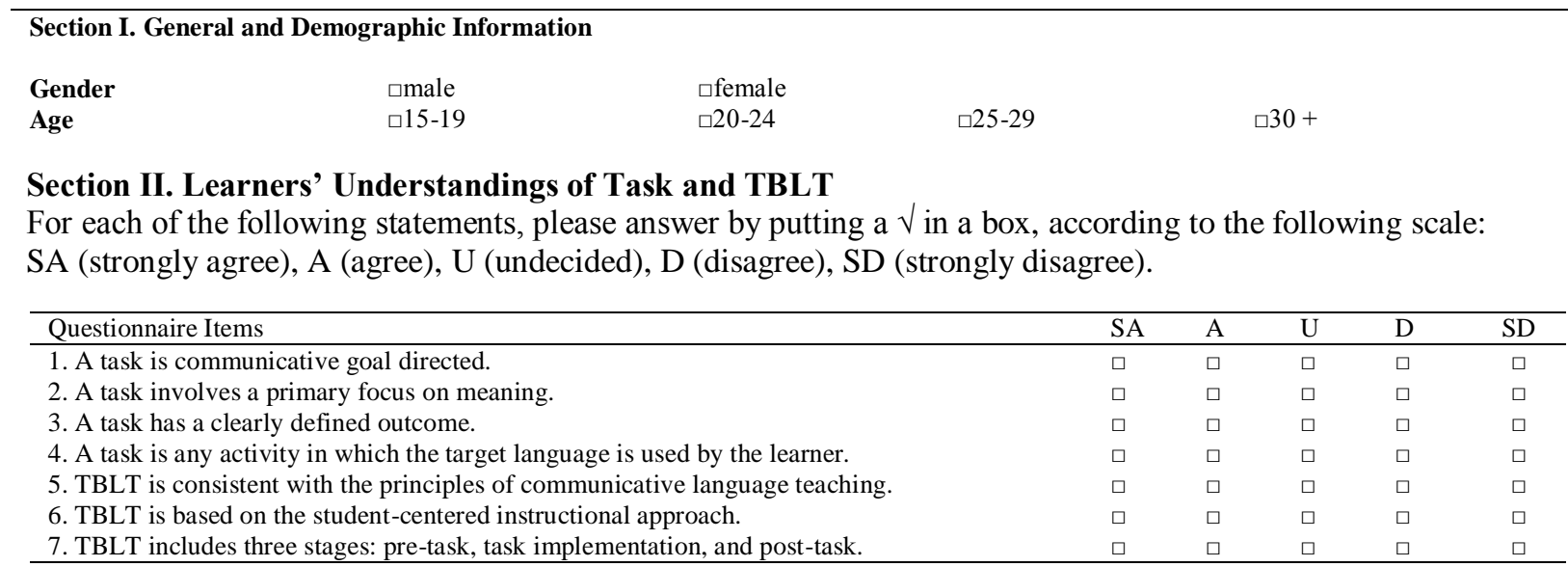

\section{Section III. Learners' Views on Implementing TBLT}

The following statements address Learners' views on implementing TBLT in the classroom. Please answer by putting a $\sqrt{ }$ in a box that matches your position most, according to the following scale:

SA (strongly agree), A (agree), U (Undecided), D (disagree), SD (strongly disagree).

\begin{tabular}{|c|c|c|c|c|c|}
\hline Questionnaire Items & SA & A & $\mathrm{U}$ & $\mathrm{D}$ & SD \\
\hline 8. I am interested in implementing TBLT in the classroom. & $\square$ & $\square$ & $\square$ & $\square$ & $\square$ \\
\hline 9. TBLT provides a relaxed atmosphere to promote the target language use. & $\square$ & $\square$ & $\square$ & $\square$ & $\square$ \\
\hline 10. TBLT activates learners' needs and interests. & $\square$ & $\square$ & $\square$ & $\square$ & $\square$ \\
\hline 11. TBLT pursues the development of integrated skills in the classroom. & $\square$ & $\square$ & $\square$ & $\square$ & $\square$ \\
\hline 12. TBLT gives much psychological burden to teacher as a facilitator. & $\square$ & $\square$ & $\square$ & $\square$ & $\square$ \\
\hline 13. TBLT requires much preparation time compared to other approaches. & $\square$ & $\square$ & $\square$ & $\square$ & $\square$ \\
\hline 14. TBLT is proper for controlling classroom arrangements. & $\square$ & $\square$ & $\square$ & $\square$ & $\square$ \\
\hline 15. TBLT materials should be meaningful and purposeful based on the real-world context. & $\square$ & $\square$ & $\square$ & $\square$ & $\square$ \\
\hline
\end{tabular}

Section IV. Reasons Learners Choose or Avoid Implementing TBLT

Are you interested in the implementation of TBLT in your classroom? $\square$ YES $\square$ NO

If yes, please put a $\sqrt{ }$ for any reasons that make you interested in TBLT. 


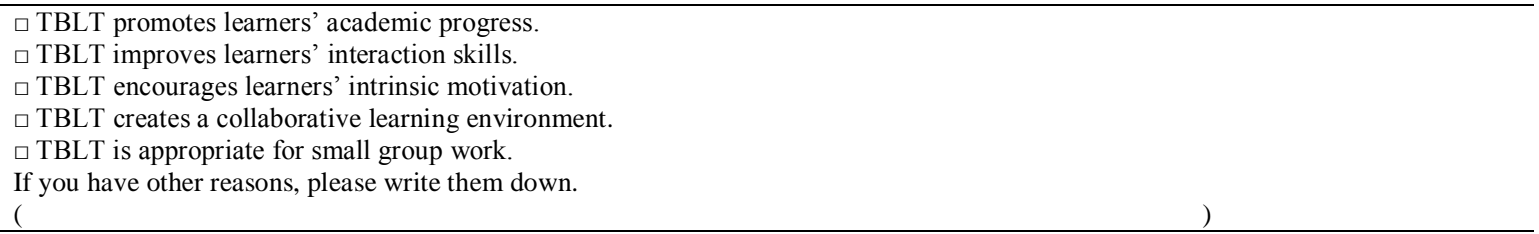

If no, please put a $\sqrt{ }$ for any reasons that make you uninterested in TBLT.

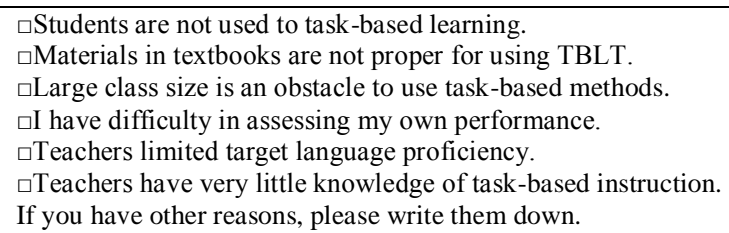

\section{REFERENCES}

[1] Barkhuizen,G. P. (1998). Discovering learners' perceptions of ESL classroom teaching/learning activities in a South African context. TESOL Quarterly, 32(1), 85-108.

[2] Block, D. (1994). A day in the life of a class: Teacher/learner perceptions of task purpose in conflict. System, 22, 473-486.

[3] Block, D. (1996). A window on the classroom: Classroom events viewed from different angles. In K. M. Bailey \& D. Nunan (Eds.), Voices from the Language Classroom: Qualitative Research in Second Language Education (pp. 168-194).Cambridge: Cambridge University Press.

[4] Brown, H. D. (2001). Teaching by principles: An interactive approach to language pedagogy. (2nd edition). Englewood Cliffs, New Jersey: Addison Wesley Longman.

[5] Burdett, J. (2003). Making groups work: university students' perceptions. International Education Journal, 4(3), $177-191$.

[6] Ellis, R. (2000). 'Task-based research and language pedagogy'. Language Teaching Research, 4(3), 193-200.

[7] Jeon, In-Jae. (2005).An analysis of task-based materials and performance: Focused on Korean high school English textbooks. English Teaching, 60(2).87-109.

[8] Jordan, R. R. (1997). English for academic purposes: A guide and resource book for teachers. Cambridge: Cambridge University Press.

[9] Kumaravadivelu, B. (1991). Language-learning tasks: Teacher intention and learner interpretation. ELT Journal, 45(2), 98-107.

[10] Lourdusamy, A., \&Divaharan, S. (2002). An attempt to enhance the quality of cooperative learning through peer assessment. Journal of Educational Enquiry, 3(2), 72-83.

[11] Nunan, D. (1988). The learner-centered curriculum. Cambridge: Cambridge University Press.

[12] Skehan, P. (1996). A framework for implementation of task-based instruction. Applied Linguistics, 17(1), 38-62.

[13] Skehan, P. \& Foster, P. (1997). Task type and task processing conditions as influences on foreign language performance. Language Teaching Research, 1(3), 185-211.

[14] Slimani, A. (1989). The role of topicalization in classroom language learning. System, 17 (2), 223-34.

[15] Williams, M. \&Burden, R. L. (1997).Psychology for language teachers. Cambridge: Cambridge University Press.

[16] Wright, T. (1990).Understanding classroom role relationships. In J. C. Richards \&D. Nunan (Eds.), Second language teacher education (pp. 82-97). Cambridge: Cambridge University Press.

[17] Zare, G. (2007). The Attitudes of the Iranian EFL Learners and Teachers towards Task-based Language Teaching. Unpublished MA thesis, Shiraz University, Shiraz.

Atefeh Hadi received her Master's degree in TEFL from Azad University, Najafabad, Iran in 2011. Her main research interests include Task-Based Language Teaching, Teachers' and Learners' Perceptions, and Computer Assisted Language Learning (CALL). 